\title{
Polymorphisms of CYP1A1 Genes and Its Correlation with Clinical Variant of Pterygium
}

\author{
Hendriati, ${ }^{1}$ Vitresia $\mathrm{H}^{2}$
}

\section{Abstract}

Background and Objective: CYP1A1 gene, which has role in carcinogenic metabolisms, is also detected in pterygium tissue. The aim of the study is to determine the polymorphisms of CYP1A1 m2 (rs1048943) and m4 (rs1799814) gene and its correlation with clinical variant of the pterygium.

Methods: DNA isolation was performed from blood sample of 80 pterygium patients consisting of 40 inflammatory and 40 non-inflammatory pterygium. Genotyping of rs1048943 SNP A $\rightarrow \mathrm{G}(\mathrm{m} 2)$ in the CYP1A1 gene was performed using Alel Specific Polymerase Chain reaction (AS-PCR) and rs1048943) SNP Genotyping was performed using PCR. Polymorphism results are characterized as wild type (AA), mutant homozygote (GG), and mutant heterozygote (AG).

Results: CYP1A1 $\mathrm{m} 2$ and $\mathrm{m} 4$ gene polymorphism consist of wild type (AA), mutant homozygote (GG), and mutant heterozygote (AG). Both CYP1A1 $\mathrm{m} 2$ and $\mathrm{m} 4$ genes polymorphism of both groups of inflammatory and non-inflammatory pterygium was mostly consist of wild type polymorphism, followed by the mutant heterozygote polymorphism. The wild type polymorphism was found to be higher in inflammatory pterygium, meanwhile the mutant heterozygote was found to be higher in noninflammatory pterygium.

Conclusion: There were differences in CYP1A1 $\mathrm{m} 2$ and $\mathrm{m} 4$ gene polymorphism in both pterygium group, but none has been shown to be statistically associated with the clinical variant of the pterygium.

Keywords: CYP1A1 gene polymorphism, inflammatory pterygium, non-inflammatory pterygium, Polymerase Chain Reaction, SNP, Genotyping

Correspondence Email: hendriati@med.unand.ac.id

${ }^{I}$ Ophthalmology Departement Medical Faculty of Andalas University, West Sumatra, Indonesia.

${ }^{2}$ Biomedical Science Doctoral Program Medical Faculty of Andalas University, West Sumatra, Indonesia

Received: 11/09/2020

Accepted: 12/11/2020 


\section{Introduction}

Pterygium has long been identified as fibrovascular tissue growth on the ocular surface, originating from the conjunctiva and proliferates toward the cornea (Bradley, J.C. et. al., 2010). It is also considered a degenerative disorder of the conjunctiva. The abnormal tissue is thought to be associated with exposure to ultraviolet (UV)-B which primarily affect corneal stem cells in the limbus. Clinically, pterygium is associated with inflammation and neovascularization. Pterygium either primary or recurrent can cause changes in normal conditions such as astigmatism, and changes in ocular surface, which eventually can lead to visual dysfunction due to decreased visual acuity (Kaufman, S.C. et. al., 2013; Hirst, L,W., 2009).

It has long been suggested that ultraviolet light exposure due to outdoor occupation is a major risk factor for the development of pterygium. Other factors associated with pterygium development are age, being male and having dry eyes (Bradley, J.C. et. al., 2010; Kaufman, S.C. et. al., 2013; Hirst, L,W., 2009). Genetic factors, tumour suppressor gene p53 and other genes may be involved in the pathogenesis of pterygium. Pterygium prevalence has found to be increased especially in countries closest to the equator line due to more sun exposure. The pathogenesis of pterygium is still not fully understood. According to the previous studies, there is a relationship between pterygium with the involvement of environmental factors such as viral infections or oxidative stress, anti-apoptotic mechanisms, mechanisms of immunology, cytokines, growth factors, extracellular matrix modulators, genetic factors, and possibly other factors (Bradley, J.C. et. al., 2010; Detorakis, E.T. et. al., 2010; Zhivov, A. et. al., 2009).

Pterygium clinical symptoms may be mild and often with no complaints at all (asymptomatic). However, some patients may also have complaints such as red eye, inflammation or irritation, burning sensation, and foreign body sensation. Clinically, Donald Tan classified pterygium as atrophic, intermediate, and fleshy. In practice, complaints and symptoms of pterygium is composed of inflammatory and noninflammatory (Bradley, J.C. et. al., 2010; Hirst, L,W., 2009; Khakshoor, H. et. al., 2010).

Environmental pollutants such as Polycyclic Aromatic Hydrocarbons (PAHs) compounds are the result of incomplete combustion of organic materials derived from environmental carcinogens and are metabolized by different xenobiotic-metabolizing enzymes, one of which cytochrome P450 (P450 or CYP). This enzyme is mainly instrumental in the change of PAHs into more polar metabolites and soluble in water, so the metabolites formed can be excreted from the body (Khakshoor, H. et. al., 2010). However, during the metabolic process, various metabolites of PAHs unstable and reactive can be formed, and these metabolites to attack DNA, causing toxicity and cell transformation. The polymorphism of CYP1A1 was previously found in pterygium tissue. Thus, it is stated that carcinogenic process was also involved in the pathogenesis of pterygium (Balci, M. et al., 2011; Shimada T., 2006). 
CYP1A1 is a sub-family 1 CYP gene superfamily, one of the important genes that encode enzymes metabolizing carcinogens, and is involved in the metabolism of carcinogenic PAHs. This gene has an important role in catalyzing the oxidative reaction Benzo (a) pyrene, which is one of the most important classes of PAHs, into reactive metabolites carcinogen. CYP1 enzymes are responsible for the activation and detoxification of various metabolites of PAHs (Shimada T., 2006; Balaji L, et al., 2012).

To our knowledge, the polymorphism of CYP1A1 gene and the relationship of CYP1A1 protein and genetic polymorphisms have not been widely discussed in pterygium. In general, several identified CYP1A1 gene polymorphism are $\mathrm{m} 1, \mathrm{~m} 2, \mathrm{~m} 3$, and $\mathrm{m} 4$. Peng et al evaluated the role of CYP1A1 allele variations in the pterygium tissue, i.e. $\mathrm{m} 2 / \mathrm{m} 2, \mathrm{~m} 1 / \mathrm{m} 2$, and $\mathrm{m} 1 \mathrm{~m} 1$. The study found CYP1A1 gene expression associated with gene allele variations, where the $\mathrm{m} 2 / \mathrm{m} 2$ allele group was found more in the pterygium tissue than the other two allele variations (Peng, M.L., et al., 2012). Variations in pterygium mutations result in different patterns of expression of growth factors, and this may explain variations in growth seen clinically (Bradley, J.C. et. al., 2010).

CYP1A1 $\mathrm{m} 1$ allele polymorphisms in both inflammatory and non-inflammatory pterygium have been evaluated in our previous study in 2017. We classified pterygium based on its clinical symptoms into inflammatory and non-inflammatory pterygium, and found that CYP1A1 m1 gene polymorphisms may occur in both pterygium groups especially in inflammatory pterygium although statistically the differences between the two pterygium groups were not significant (Hendriati, H. et. al.,2017). One year later, we also studied the correlation between CYP1A1 $\mathrm{m} 1$ gene polymorphism with CYP1A1 enzymes, p53 protein, and VEGF levels in pterygium. We found that CYP1A1 gene polymorphism did not affect the levels of CYP1A1 enzymes, p53 protein and VEGF in both pterygium groups (Hendriati, H. et. al.,2018). Therefore, in this study we aim to determine the polymorphism of CYP1A1 m2 (rs1048943) and m4 (rs1799814) gene and its correlation with clinical variant of the pterygium (inflammatory and non-inflammatory pterygium).

\section{Materials and methods}

This study was an observational study with cross sectional study comparative study design. We obtained 80 samples of pterygium tissues which consist of 40 inflammatory and 40 non-inflammatory pterygium from our previous study in 2017.

The study populations were all pterygium patients. The study sample is part of the population that meets the inclusion and exclusion criteria, both for inflammatory and non-inflammatory pterygium. The approximate size of the minimum sample is calculated based on the formula of hypothesis test of 2 different proportions. From that calculation, we obtained minimum samples number of 40 people for each group, thus the total sample was up to 80 patients. 
The inclusion criteria were all patients diagnosed with primary pterygium both unilaterally and bilaterally, meeting the criteria of surgical indication, either clinical or cosmetic indications, not receiving anti-VEGF therapy or steroids in the last 2 weeks, and agreed to participate in this study. Exclusion criteria were patients suffering from anterior segment infection (conjunctivitis and keratitis) and patients suffering from other disorders in the conjunctiva, such as benign and malignant lesions of the conjunctiva.

\section{Isolation of Genomic DNA}

Genomic DNA was isolated from $300 \mu \mathrm{L}$ of blood sample using GF-1 Blood DNA Extraction Kit Vivantis. DNA isolation was performed in accordance with the kit procedure consisting mainly of the sample preparation stage, cell lysis stage, DNA binding stage, leaching stage, and the elution stage of DNA.

\section{Genotyping rs1048943 $(\mathrm{A} \rightarrow \mathrm{G})(\mathrm{m} 2)$}

Genotyping SNP rs1048943 $(\mathrm{A} \rightarrow \mathrm{G})$ in the CYP1A1 gene was performed by AS-PCR using the specific primary alel P57(A) dan P58(G). Then, the PCR products were analyzed using electrophoresis on a gelose gel of $1.5 \%$ which had been dyed GelRed DNA, then observed with GelDoc. Individuals who have a wild type genotype (AA allele) will produce DNA bands of $972 \mathrm{bp}$. Individuals who have the heterozygous genotype (AG allele) will produce DNA bands from both A and G. Individuals who have genotype of mutant homozygotes (GG allele) will produce specific allele of G. As confirmation of PCR results, some samples of purified PCR products will be sent to Macrogen, South Korea for sequencing.

\section{Genotyping rs1799814 $(\mathrm{A} \rightarrow \mathrm{G})(\mathrm{m} 4)$}

Genotyping SNP rs1048943 $(\mathrm{A} \rightarrow \mathrm{G})$ in the CYP1A1 gene was performed by PCR sequencing using the specific primary alel 142-F and 969-R (Figure 1). Then, the PCR products were analyzed using electrophoresis on a gelose gel of $1.5 \%$ which had been dyed GelRed DNA, then observed with GelDoc.

The remaining PCR products were purified by the cold Na-acetate and Ethanol Absolute method. Furthermore, about $20 \mu \mathrm{l}$ of pure PCR products were sent for sequencing to Macrogen, South Korea. The sequencing method used is the Sanger method. Sequencing data were analyzed with the help of Geneious bioinformatics software. The sequencing data for each sample from the forward primer is combined with the sequencing data from the reverse primer. Furthermore, the contig data is BLAST on the NCBI website. 


\section{Results}

We obtained 80 pterygium tissues from 80 patients which consist of 40 inflammatory and 40 non-inflammatory pterygium. CYP1A $1 \mathrm{~m} 2$ and $\mathrm{m} 4$ gene polymorphisms found in inflammatory and non-inflammatory pterygium were further divided into wild type, mutant homozygote and mutant heterozygote. Most of polymorphisms was found in all samples except the mutant homozygous polymorphism which is absent in both genes and in both group of pterygium. In both pterygium groups, wild type was found to be higher than the mutant heterozygous and homozygous polymorphism. Table 1 shows the CYP1A1 m2 polymorphism in both pterygium groups.

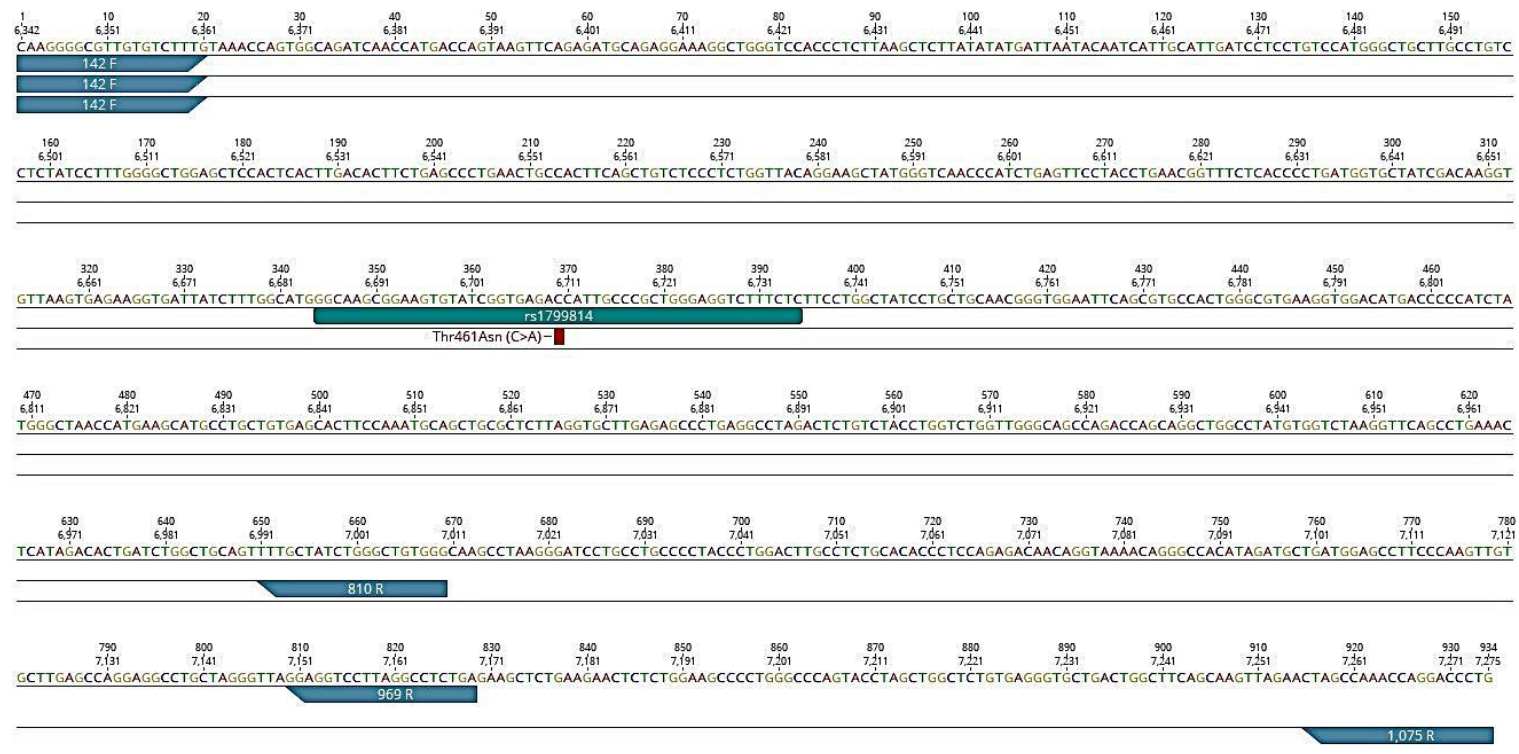

Figure 1: The primary allele $142-\mathrm{F}$ and $969-\mathrm{R}$

Table 1: CYP1A1 $\mathrm{m} 2$ polymorphism in both pterygium groups

\begin{tabular}{lcccc}
\hline \multicolumn{1}{c}{ Pterygium } & $\begin{array}{c}\text { Wild } \\
\text { Type } \\
(\mathrm{AA})\end{array}$ & $\begin{array}{c}\text { Mutant } \\
\text { Heterozygote } \\
(\mathrm{AG})\end{array}$ & $\begin{array}{c}\text { Mutant } \\
\text { Homozygote } \\
(\mathrm{GG})\end{array}$ & Total \\
\hline Inflammatory & 26 & 14 & 0 & 40 \\
Non- inflammatory & 22 & 16 & 2 & 40 \\
Total & 48 & 30 & 2 & 80 \\
\hline
\end{tabular}

Based on table 1, wild type CYP1A1 $\mathrm{m} 2$ polymorphism was the most common polymorphism found in both groups followed by the mutant heterozygote. The wild type CYP1A1 m2 polymorphism was found higher in inflammatory group compared to noninflammatory group. Meanwhile, the mutant heterozygote CYP1A1 m2 polymorphism was higher in non-inflammatory group. Mutant homozygote CYP1A1 m2 polymorphism 
was absent in inflammatory group. Table 2 shows CYP1A1 $\mathrm{m} 4$ polymorphism in both pterygium groups.

Table 2: CYP1A1 m4 polymorphism in both pterygium groups

\begin{tabular}{lcccc}
\hline \multicolumn{1}{c}{ Pterygium } & $\begin{array}{c}\text { Wild } \\
\text { Type } \\
\text { (AA) }\end{array}$ & $\begin{array}{c}\text { Mutant } \\
\text { Heterozygote } \\
\text { (AG) }\end{array}$ & $\begin{array}{c}\text { Mutant } \\
\text { Homozygote } \\
\text { (GG) }\end{array}$ & Total \\
\hline Inflammatory & 27 & 13 & 0 & 40 \\
Non- inflammatory & 24 & 14 & 2 & 40 \\
Total & 51 & 27 & 2 & 80 \\
\hline
\end{tabular}

Based on Table 2, wild type polymorphism was also the most common polymorphism found in $\mathrm{m} 4$ gen polymorphism followed by the mutant heterozygote. In similar pattern with the CYP1A1 m2 gene polymorphism, the wild type CYP1A1 $\mathrm{m} 4$ polymorphism was found higher in inflammatory group compared to non-inflammatory group. Meanwhile, the mutant heterozygote CYP1A1 m4 polymorphism was higher in non-inflammatory group. Mutant homozygote CYP1A1 m4 polymorphism was absent in inflammatory group.

\section{Discussion}

Cytochrome-P450 1A1 (CYP1A1) is included in the important superfamily of cytochrome P450 (CYPs) involved in the metabolism of many xenobiotic compounds and endogenous lipophilic substances, which can activate procarcinogen into DNA reactive metabolites (Shimada T., 2006; Tung, J.N. et. al.,2010; Shehadeh, M.R. et. al.,2011). The human CYP1A1 gene is located on chromosome 15q22-24, composed of seven exons responsible for procarcinogen activation of reactive metabolites and is involved in oxidation mediation, including polycyclic aromatic hydrocarbons and aromatic amino to mutagenic and carcinogenic metabolites. CYP1A1 genetic polymorphism may cause changes or loss of CYP1A1 enzyme activity, and result in cellular detoxification damage, which can lead to the absence of cell growth suppression mechanisms (Shehadeh, M.R. et. al.,2011; Jaworski, C.J. et. al.,2009; Young, C.H. et. al.,2010).

Tung et al (2010) studied the association of CYP1A1 allele variants and protein expression in primary culture epithelial cells. The association of CYP1A1 allele variants with CYP1A1 protein expression in the mutant homozygote $\mathrm{m} 2 / \mathrm{m} 2$ group was significantly higher than the wild type $\mathrm{m} 1 / \mathrm{m} 1$ and mutant heterozygote $\mathrm{m} 1 / \mathrm{m} 2(\mathrm{p}=0.027)$. In the control group of normal conjunctive tissue there was no significant relationship (Tung, J.N. et. al.,2010).

In our previous study, we found that CYP1A1 $\mathrm{m} 1$ gene polymorphism was found in both pterygium groups. Mutant heterozygote polymorphism is a more common form of polymorphism in both groups compared to homozygote and wild type mutant forms. In both pterygium groups, each form of polymorphism was found to be almost 
similar in both inflammatory and non-inflammatory pterygium, so there was no significant difference between the two groups (Hendriati, H. et. al.,2017).

In this study, we also found CYP1A1 $\mathrm{m} 2$ and $\mathrm{m} 4$ gene polymorphism in form of wild type, mutant heterozygote and mutant homozygote polymorphism. In contrast to our previous study, wild type is the most common type of polymorphism found in both $\mathrm{m} 2$ and $\mathrm{m} 4$ genes compared to mutant heterozygote and mutant homozygote polymorphism. The wild type M2 and M4 gene polymorphism was found to be higher in inflammatory group compared to non-inflammatory group, meanwhile the mutant heterozygote was found to be higher in non-inflammatory group. On the other hand, mutant homozygote $\mathrm{m} 2$ and $\mathrm{m} 4$ polymorphism was found only in non-inflammatory pterygium.

\section{Conclusion}

The results of this study indicate the presence of polymorphisms in the CYP1A1 $\mathrm{m} 2$ and m4 gene either in the form of wild type (AA) mutant homozygote (GG), and mutant heterozygote (AC). This study showed that the polymorphisms in the CYP1A1 m2 and m4 genes that were most found in the inflammatory and non-inflammatory pterygium groups were wild type. This is different from our previous study which found more heterozygote mutant polymorphisms in the two groups of pterygium even though the differences found were not significant. Therefore, differences in variants of the CYP1A1 gene polymorphism found in the two groups of pterygium are thought to be related to the mechanism of pterygium formation and the clinical symptoms it creates.

\section{Acknowledgement}

This research is funded by Penerimaan Negara Bukan Pajak (PNPB) grant funds of 2018 and is a further research of our previous study of CYP1A1 m1 gene polymorphism published in 2017.

\section{References}

Balaji L, Singh KB, Bhaskar LVKS. (2012). CYP1A1 Genotypes and Haplotypes and Risk of Oral Cancer: A Case-Control Study in South Indians. Genet. Mol. Biol., 35(2), 407-412. https://www.scielo.br/scielo.php?script=sci_arttext\&pid=S141547572012000300004\&lng=en\&tlng=en

Balci, M., Şahin, Ş., Mutlu, F.M., Yağci, R., Karanci, P., Yildiz, M. (2011). Investigation of Oxidative Stress in Pterygium Tissue, Mol. Vis., 17, 443-447. http://www.molvis.org/molvis/v17/a50/

Bradley, J.C., Yang, W., Bradley, R.H., Reid, T.W., Schwab, I.R. (2010). The Science of Pterygia. Br. J. Ophthalmol., 94(7), 815-820. https://bjo.bmj.com/content/94/7/815.long

Detorakis, E.T., Zaravinos, A., Spandidos, D.A. (2010). Growth Factor Expression in Ophthalmic Pterygia and Normal Conjunctiva. Int. J. Mol. Med., 25(4),513-516. https://www.spandidospublications.com/ijmm/25/4/513

Hendriati, H., Yanwirasti, Y., Gondhowiardjo, T.D., Tjong, D.H. (2018). The Association of CYP1A1 Gene Polymorphisms with CYP1A1 Enzymes, P53 Protein, and Vascular Endothelial Growth 
Factor Levels in Pterygium, Proceedings of the 1st EAI International Conference on Medical And Health Research, ICoMHER, 2018, 1-10. https://eudl.eu/doi/10.4108/eai.13-112018.2283641

Hendriati, Yanwirasti, Gondhowiardjo, T.D., Tjong DH. (2017). CYP1A1 Gene Polymorphism in Inflammatory and Non-Inflammatory Pterygium. J. Med. Sci., 17(1), 26-30.

https://scialert.net/abstract/?doi=jms.2017.26.30

Hirst, L,W. (2009). Recurrent Pterygium Surgery Using Pterygium Extended Removal Followed by Extended Conjunctival Transplant: Recurrence Rate and Cosmesis. Ophthalmology., 116(7), 1278-1286. https://linkinghub.elsevier.com/retrieve/pii/S0161-6420(09)00106-7

Jaworski, C.J., Aryankalayil, J.M., Campos, M.M., Fariss, R.N., Rowsey, J., Agarwalla, N., Reid, T.W., Dushku, N., Cox, C.A., Carper, D., Wistow, G. (2009). Expression Analysis of Human Pterygium Shows A Predominance of Conjunctival and Limbal Markers and Genes Associated with Cell Migration, Mol. Vis., 15, 2421-2434. http://www.molvis.org/molvis/v15/a258/

Kaufman, S.C., Jacobs, D.S., Lee, W.B., Deng, S.X., Rosenblatt, M.I,. Shtein, RM. (2013). Options and Adjuvants in Surgery for Pterygium: A Report by the American Academy of Ophthalmology. Ophthalmology., 120(1), 201-208. https://linkinghub.elsevier.com/retrieve/pii/S0161-6420(12)00696-3

Khakshoor, H., Razavi, M.E., Daneshvar, R., Shakeri, M.T., Ghate, M.F., Ghooshkhanehi, H. (2010). Preoperative Subpterygeal Injection Vs Intraoperative Mitomycin C for Pterygium Removal: Comparison of Results and Complications. Am. J. Ophthalmol., 150(2), 193-198. https://www.ajo.com/article/S0002-9394(10)00220-5/fulltext

Peng, M.L., Tsai, Y.Y., Tung, J.N., Chiang, C.C., Huang, Y.C., Lee, H., Cheng, Y.W. (2014). Vascular Endothelial Growth Factor Gene Polymorphism and Protein Expression in The Pathogenesis of Pterygium. Br J Ophthalmol., 98(4), 556-561. https://bjo.bmj.com/content/98/4/556.long

Shehadeh, M.R., Srinivasan, S., Boimer, C., Lee, K., Tomkins, O., Slomovic, A.R. (2011). Management of Recurrent Pterygium with Intraoperative Mitomycin $\mathrm{C}$ and Conjunctival Autograft with Fibrin Glue. Am. J. Ophthalmol., 152(5), 730-732. https://www.ajo.com/article/S0002-9394(11)00374-6/fulltext

Shimada T. (2006). Xenobiotic-Metabolizing Enzymes Involved in Activation and Detoxification of Carcinogenic Polycyclic Aromatic Hydrocarbons. Drug Metab. Pharmacokinet., 21(4), 257-276. https://www.jstage.jst.go.jp/article/dmpk/21/4/21_4_257/_article

Tung, J.N., Wu, H.H., Chiang, C.C., Tsai, Y.Y., Chou, M.C., Lee, H., Cheng, Y.W. (2010). An Association between BPDE-Like DNA Adduct Levels and CYP1A1 and GSTM1 Polymorphisma in Pterygium. Mol Vis., 16, 623-629. http://www.molvis.org/molvis/v16/a71/

Young, C.H., Lo, Y.L., Tsai, Y.Y., Shih, T.S., Lee, H., Cheng, Y.W. (2010). CYP1A1 Gene Polymorphisms As A Risk Factor for Pterygium, Mol. Vis., 16, 1054-1058. http://www.molvis.org/molvis/v16/a117/

Zhivov, A., Beck, R., Guthoff, R.F. (2009). Corneal and Conjunctival Findings After Mitomycin C Application in Pterygium Surgery: An In-Vivo Confocal Microscopy Study. Acta Ophthalmol., 87(2), 166-172. https://onlinelibrary.wiley.com/resolve/doi?DOI=10.1111/j.17553768.2008.01198.x 